\title{
The Role of Female Participation on Economic Activity: Cross Sectional Data
}

\author{
GETINET GEZAHEGN GEBRE \\ Lecturer, Department of Economics, Bonga University, Ethiopia
}

\begin{abstract}
This study investigates the role of female participation on the economic activity, in the case of Bonga Town of south west region which is the capital city of Kafa Zone and $4490 \mathrm{~km}$ south west of Addis Ababa. The general objective of the study is to assess the role of female Participation on the economic activity in Bonga . The specific objectives were to examine the role of female Participation on the economic activity. Female participation on economic activity is essential not only for achieving inequality in the society but also for reducing poverty. The research primarily used Primary data collected from the sample study through questionnaires. It also used Secondary data obtained from reviewing available materials. The study used descriptive method to describe and interpret the details of female participation on economic activity. Data were evaluated by using SPSS. The study found that female participation in economic activities enable in speeding growth by increasing productivity, food security, reduce poverty, and promote efficiency, helping future generation and sustainable development. It also allows personal well-being, households to feed themselves and their family members, better housing condition and nutrition. The study also identified some challenges that the female face in their economic activity such as Lack of access to credit both formal and informal and legal regulatory barriers that prevent female in some area of the study from full participation in economic activity.
\end{abstract}

Keywords: Women, Education, Economic activity and poverty

DOI: $10.7176 / \mathrm{EJBM} / 12-10-05$

Publication date: April $30^{\text {th }} 2020$

\section{INTRODUCTION}

Female make up 40 percent of the World's work force in Agriculture. Female farmers in the developing countries grow at least $50 \%$ of world's food much as 805 in some Africa countries. In addition to income generating activity (in cash and kind) female's household activities include caring children, maintenance and such as works caring children, preparing food, and fetching water \&collecting fire wood. Yet female productivity remains low both income generating work \& home production (Bosrup, 2010).

According to (BOFED, 2017) data of the total population of Bonga town was 28,000. From the total population $52.72 \%$ were female. When we see in age females whose age greater than 15 years and less than 15 years are $57 \%$ and $43 \%$ respectively.

In SNNPR region females are actively involved on all aspect of their society's life. The fact that females are produce as well as active participants in the social, political \& cultural activities of their communities has enabled them to play an all-round role (ORSAB, 2007).

Female constitute proportionally a large group as the labor force in various economic activities. Therefore, economic development is unthinkable without the participation as female. However, today, Ethiopian female have not been able to equally benefit from the nation's wealth the cause their labor and their participation in economic activity have not been duly valued (ILO, 1986). Females in economically Developed countries are better condition than female in economically LDCs \& their participation (yirgedu, 2011).

\section{Statement of the problem}

Female have believed to have played a triple role in society. That is reproductive role, productive role and participation in economic activity can help to reduce poverty and wage differences between men and female and also create employment opportunity (Todaro and Smith 2009). Although female like men have been activity engaged in productive, several of the community affairs, their contribution remains invisible and unrecognized, the generation of household wealth and national wealth in never recognized. National accounting system have never found a way as recording the value as households good and services mostly generated by female in the calculation as GDP( Boserup, 2000).

Female participation in economic activity has become increasingly important for promoting growth, promoting efficiency, food security and helping future generation. However, knowledge above the achievement of these strategies remains only partial and controversial (World Bank, 1994).

In Ethiopia culture there is a belief that the proper role of female is one that confined to mother hood and management of home. As a result of such attitudes and perceptions Ethiopian female have missed out of many economic activities and the role of participation is not properly valued (EEA, 2000).

As a researcher from our observation and examination that the above mentioned problems concerning the 
economic participation of female such as remaining of their contribution invisible, unrecognized and being confined to Mother hood and management as home are visible in Bonga town also.

The problems may be related to Cultural attitudes towards female limit the effective participation of female in the economic activities. The impact of female participation in economic activities on household is not yet addressed and the contribution of female on the economy generally is not recognized.

The scope of the study was mainly of female participation on the economic activity, thus the main issues focused were agriculture and informal \& formal sector related issues. Further, study focus on south west Kafa zone mostly in Bonga town due to time, finance, $\&$ other resources.

This paper includes five chapters. The first chapter deals with the introduction of the study which include, back ground, statements of the problem, objective, significance, and scope of the study. The second chapter deals with literature review of the study which includes theoretical and literature review. The third chapter deals with methodology of the study which includes data types and sources, data collection method, sampling procedure , sampling techniques and methods of data analysis. The fourth chapter deals with data analysis and interpretation which includes the role of female participation in the economic activities on the household, economy, problems observed as barriers of female effective participation in economic activity and government function. The fifth chapter deals with conclusion and recommendation.

\section{LITERATURE REVIEWS}

\section{Theoretical Literature}

Females role in economic development in a most low income developing countries household, female have a triple role. Female's roles include reproductive work mat is required to guarantee the maintenance and reproduction of the labor force, productive work and community managing work. In rural areas, their productive role usually takes informal sector and small enterprises located either in the home or neighbor hoods. Women's community handling work involves the provision of items for collective consumption under taken in the local community in both urban and rural situations (Moser, 1990).

An improvement planning whether national has traditionally been gender neutral. This was partly and that aid organization where followed with very little in sight in to gender because until recently lacked information about female and their contribution to their regions. As a result there was a tendency to marginalize female by development planners who have often seen them only as passive beneficiary of social and health services. Development must be a human centered process, because people are both the means and end of development. Planners must also realize that development. Goals will only be reached by securing the active involvement of female's as well as men and by bringing female's in to the main stream of economic development so that each gender plays it respective role in the processes (IBID).

Economic history has strongly influenced female. Pre- monetary clear and complementary division of labor had quite men, female, boys and girls with the beginning of sedentary life, female's work in much of the continent become food farming with men doing the hunting, heavy clearing and perhaps some harvesting and winnowing. Female battered in order to meet family needs. Ten years ago, policy making for Africa female actives and concerns was necessary "planning without fact" access to education, independence and sophistication of female organizations. For policy and aid purpose there has been a major development in the documentation of women's economic and family's role and in understanding the track of policy implementation for feminine from the international to the local level.(Moser, 1993). As important contribution of domestic economy Ethiopian female have played a traditional role of mother and house wife in both rural and urban areas of Ethiopia. However, their works have never been limited to the households and the family. Female's productivity is predominant on the processing and marketing of food and linked cottage industries.

Obviously, more and more female have moved in to activities which are monetary rewarding along a pattern were by the higher wages prevailing in the urban modern sector are pulling female out of the subsistence economy. Job searching takes place in the most case on arrival in urban areas. Labor mobility in urban areas takes place mainly from informal to formal sector with the former being a transit point while the latter is the final destination.

\section{EMPERICAL REVIEW}

The Condition of Ethiopian Female, about 88 percent of Ethiopians live in the rural areas because of the basic of the methods of production used in the rural areas, nearly 85 percent of female's labor and animal has boundary activities in which traditional technique of production as applied. Even though, the division of labor differs from place to place depending on the climatic condition female participate in all types of agricultural work, including weeding, ranking, harvesting and preparing trashing field and trains bins. Example, female in nomadic society are enlisted with the responsibility of enacting mobile next place of stay, in addition of cattle raising and herding with respect to house work, rural female have to grind grain, fetch water, gather fire wood, prepare food and raise children and sweat out for about 13 to 17 hours a day. 
Under the urban areas, majority of the low - wage earner in the urban area are female. In the factories, for instance, female make up 30 percent of the labor paid is only 21 percent. Although, every small number of female hold high position job that require college training and technological know-how, but Ethiopian female are engage in all types of old jobs. These include low income job, such as selling integral the pancake like traditional food and tells the traditional bravery, working as a house Medias is, of course, the first occupation most young female who move to cities from rural areas in search of a better life embark on (MoLSA), 1988).

\section{METHODOLOGY}

\section{Data type and source}

The data for the study obtained from both primary and secondary data source. Primary data the major sources of data was obtained from sample study, structured and unstructured questionnaires and Secondary data for the study obtain from reviewing available literature, books, and magazines, written document, both published and unpublished, different booklets and annual reports from the organization.

To collect the required information, the researcher was employed three different types of data gathering tools. These were questionnaires, interview and observation. A questionnaire was both open ended and closed ended questionnaires were arranged and interviewing by the researchers from society who has been included in the sample size. Interview was arranged and conducted with organization team to gather sufficient information and the observation have been also used by researchers by watching some events occurred in the area in order to obtain additional data or secondary data. The researcher choose this method because it provides current information, save time, cost especial questionnaires are free from bias in inter viewer.

As a researcher have planned to use simple random sampling method Out of the total population 28000 of study area, random sampling of 100, of citizens were drown from the total population of the area 50, for participants and 50, for non - participants. Let's to calculate sampling by formula

$\mathrm{n}=\mathrm{N} / 1+\mathrm{N}\left(\mathrm{e}^{2}\right)$

$$
\mathrm{n}=\text { sampling size }
$$

$$
\begin{aligned}
& \mathrm{N}=\text { Total population }(\mathrm{N}=28,000) \\
& \mathrm{e}=\text { sample error }(\text { To take a } 10 \text {, degree level of significance }=0.1)
\end{aligned}
$$

$\underline{\mathrm{n}=99.6}$

The sampling that a researcher used out of four kinds of probability sampling methods, simple random was employee because this method of data collection is simple and avoids the probability of making personal bias .It would easier for the researcher to administer and number of the unit is simple for a given cost.

In order to achieve the objective of the study, descriptive method was used to describe and interpret the details of female participation on economic activity depending on the type and nature of data gathered from the structured questionnaires.

In analysis is the data, the information was grouped into qualitative and quantitative. The data result was organized and summarized in tables, frequency, and percentage. So that meaningful interpretation of the result made so as to draw conclusion and recommendation.

\section{DATA ANAYSIS AND INTERPRETATION}

\begin{tabular}{lll}
\hline Age & Number & Percent \\
\hline Less than 18 & 12 & $12 \%$ \\
$\mathbf{1 8 - 3 4}$ & 58 & $58 \%$ \\
Greater than $\mathbf{3 4}$ & 30 & $30 \%$ \\
Total & 100 & $100 \%$ \\
Educational level & & \\
Illiterate & 9 & $9 \%$ \\
Primary education & 15 & $15 \%$ \\
Secondary education & 46 & $46 \%$ \\
Higher education & 30 & $30 \%$ \\
Others & - & - \\
Total & 100 & $100 \%$ \\
\hline Source: & & \\
\hline
\end{tabular}

Source: own computation

As the above table indicates the majority of the respondents lie in the age range from $18-34$, i.e. $58 \%$ of the respondents. 30 respondents said that their age is greater than $34 \%$ of the respondents. The rest $12 \%$ of the respondents stated that their age is lesser than 18. Therefore, the dominants relatively younger respondents. Another characteristic of the respondents is their educational level. From the total 100 respondents most have attended high education, i.e. $30 \%$ of the respondents. $46 \%$ of the respondents have attained secondary education of the respondents $15 \%$ replied that they have primary education while the rest $9 \%$ do not have any formal 
education. These conclude that most of the respondents have a good educational background and the reason is that they are urban residents who have high access to education facilities.

Female participation in the economic activities is expected to improve the long term economic and social of its house hold, through wealth creations, income, asset building and the like. Many studies indicate that female participation in the economic activity has a positive impact when we examine whether this scenario ascertain in Bonga Town have the same impact. Improvement in the household living standard may be observed from trended and diversification of income source, food security strategies for coping up difficulties, education of children ,food consumption pattern and ownership of key specific assets. However, the aforementioned factors are not solely affected by improvement in come. Therefore, an attempt has been made to look in the possible ways of measuring the impact of woman participation in the economic activates on house so as to make robust conclusion.

From the table: it was possible to observe version in the trend of income between the participant female and non-participant female in economic activity. Example, in the table 4.4 in the study area 70.2 percent of the respondents registered increase in their income for the last 12 months, while only 26.6 percent of non-participant indicated that income has shown increment.

Table: Trend of income during the last 12 months $(2018 / 2019)$

\begin{tabular}{lllll}
\hline \multirow{2}{*}{ Trend } & \multicolumn{3}{l}{ Respondent } \\
\cline { 2 - 5 } & \multicolumn{2}{l}{ Participant in economic activity } & \multicolumn{2}{l}{ Non - Participant in economic activity } \\
& Number of Respondent & Percent & Number of Respondent & Percent \\
Increase & 38 & $70.2 \%$ & 18 & $26.6 \%$ \\
Decrease & 7 & $16.6 \%$ & 7 & $23.4 \%$ \\
Stayed the same & 5 & $13.2 \%$ & 25 & $50 \%$ \\
Total & 50 & $100 \%$ & 50 & $100 \%$ \\
\hline
\end{tabular}

Source own computation

Table: indicates that 70.2 percent of the respondent they participate in the economic activates that there over all house hold income has increased during the last 12 months(2018/19).Taking, on the other hand nonparticipant female that their overall house hold income has increased only 26.6 percent during the same period. As a result of these analysis accept the hypothesis that assumes female participation in the economic activities improve the income for the household.

On the other hand, participant were found to be better than non-participant in food expenditure, which may indicate that participating in the economic activates, has helped the family in the study area to smooth their income by helping them get access to food.

\section{Building Assets}

The case study asses the impacts of female participation in the economic activates on the household accumulation of asset. This is because ownership of durable household's assets is regarded as one of the most important indicators of improvement in the household welfare. In this regard, in addition to the impact on the overall household income, female participation in the economic activates is also expected to improve the ownership of key household assets. Accordingly, the assumption deals with ownership of different appliances and furniture in the study area of both participant and non-participant female.

Table: ownership of radio/tape in the study area

\begin{tabular}{lllllll}
\hline Types of Respondent & \multicolumn{7}{l}{ Do you have radio/type? } & & \\
\cline { 2 - 8 } & YES & NO & & TOTAL \\
Participant in the economic activates & 50 & $100 \%$ & 0 & 50 & $100 \%$ \\
Non - participant in the economic activates & 35 & $63.3 \%$ & 15 & $26.7 \%$ & 50 & $100 \%$ \\
\hline
\end{tabular}

Source; own computation

Table 4.4 indicates that all the respondents of the participant in the economic activities had radio/tape. The case study result showed that 100 percent of the respondents in the economic participant female have been the ownership of the radio/tape. On the other hand non-participant female show that 63.3 percent of the respondents have been the owner ship of tap/radio. As a result of this can accept the hypothesis on female participation in the economic activities of building asset to the household.

\section{Housing Improvement}

It is a well-established fact that housing and its related investment is key indicator of a country's development . This is because investment can serve a useful purpose both to increase the household's standard of living and to improve its income generating opportunities. Apart from serving people as shelter, house is the most valuable asset people should have when the house is improved; its value boosts and thereby increases a household material wealth. In this ways, housing improvements can be an integral part of household member's 
long term economic strategies. Hence, the assumption of these variable is that participation in the economic activates have better housing condition than of non-participants (seen figure below)

Figure: Housing improvement

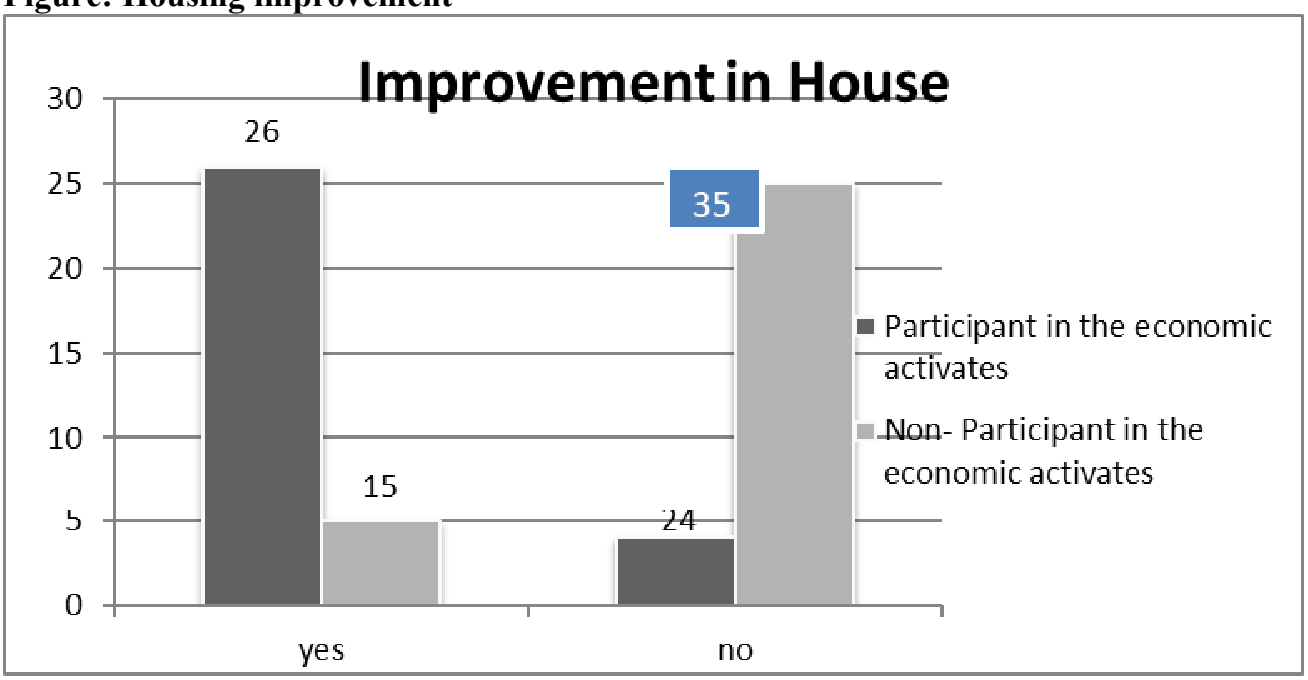

Source own computation

That is, if household have access to large capital through economic participation, they will be engaged in more profitable and productive activities thereby increasing their income level. As a result, they have better capacity to improve their residential and business house through repair of building additional rooms from the profit of economic participation activities. Housing improvement can range from adding new rooms to installing electricity or telephone.

The finding clearly indicate that there was a positive impact on house improvement of participant female in economic activates. From the table $4.386 .6 \%$ of improve their house after participating in economic activates .On the other hand non-participant female improve only 16.7 percent of the respondent.

\section{Diet and coping up with difficulties}

The condition of diet or nutrition is an important factor in well- being of the household members. The assumption that when people are better feed, or well nutritional them will be more productive. As a result, they will be contributed to the development of their community and their country at large. Consider the participant and non-participant female in economic activity of female. The former were expected to have a better household diet condition and house hold diet was used as variable indicator of this hypothesis .Accordingly, respondents were asked whether their house hold diet was improved or not during the last two years(before 2018/19)

Table: Nutritional status of the respondents during the last two years (before 2018/19)

\begin{tabular}{lllll} 
Trends & Participant & \multicolumn{2}{c}{ Non - participant } \\
\cline { 2 - 5 } Increase & Number & Percent & Number & Percent \\
Decrease & 32 & $73.3 \%$ & 13 & 26.6 \\
Stayed the same & 6 & $10.1 \%$ & 11 & 20.1 \\
Total & 12 & $16.6 \%$ & 26 & 53.3 \\
\hline Source & 50 & 100 & 50 & 100 \\
\hline
\end{tabular}

Source own computation

Table: indicates that for 73.3 percent of the respondent from the participation in the economic activity have shown a increasing trends in the nutritional status of the food their family consume. On the other hand, the respondent of non- participant in the economic activities have not been in a good position when it comes to nutrient over the two years (before 2018/19). As a result ,can accept the initial hypothesis that female participation in the economic activities improves nutritional status of the households.

\section{Access to Education}

Once the income problem is solved, people look for mechanism of fulfilling other need such as education and health. The assumption that households with the higher income level have more choices and broader opportunity for the higher income level has more choices and broader opportunity for an attainment. Studies indicate the involvement in the economic activities and access to education are positively related .Therefore, the hypostasis of this section is that in addition to improving income, housing and owner ship of key household asset, participation in the economic activities is also expected to improve the possibility of additional expenditures for educational beneficiaries of household members. 
Table: Trends of Access to Education

\begin{tabular}{lllll}
\hline Types of respond ant & Participant & \multicolumn{3}{c}{ non participant } \\
\cline { 2 - 5 } Increasing & Number & Percent & Number & Percent \\
Decreasing & 38 & $83.3 \%$ & 16 & $53.3 \%$ \\
Total & 12 & $16.7 \%$ & 14 & $46.7 \%$ \\
\hline
\end{tabular}

Source own computation

The above table: indicates that to school, respondent of the participant female were better than that of non participant female. This is the participant female is $83.7 \%$ but the non-participate female is only $53.3 \%$ on the other hand, the decrement trend is in the non- participant female than that of female participant in the economic activates. As a result of this, accept the hypothesis of female participant in the economic activates improve access to education.

\section{Female participation on the Economy}

Female participation in the economic activity is critical for economic growth and development .It speeds growth by rising productively and promoting the efficient use of resources. Based on this assumption, the respondent suggested the following impacts of female participation in economic activity on the economy

\section{Promoting Efficiency and Reducing Poverty}

Also as table: indicates, female participation in the economic activates promote efficiency and reduce poverty. This is suggested by $13.3 \%$ for both. According to the respondent, female participation is major theme of strategy of poverty reduction. This strategy broadly based on labor absorbing economic growth to develop and use efficiently the poor's smooth the abundant asset activity shown as in bar graph.

The respondents suggest that the extent which female are over represented among the poor, programs aimed at enhancing female's economic activates participation and programs aimed at enhancing female's economic activities participation and productivity are highly computable with targeted approaches to poverty reduction.

They also suggested that financial institutions that provide credit to the poor, among whom female figure significantly showed that its economic impact among participation with substantial, reducing poverty more than in non-participant female of the study area.

Female participation in the economic activities has also impact o helping future generation and promoting sustainable development and other. This suggests that out of the total respondent $12.6 \%, 11.3 \%$ and 9.3 respectively. Other including avoiding informal sector, traditional customs and social return alternatively female participate in economic activity shown as in bar graph.

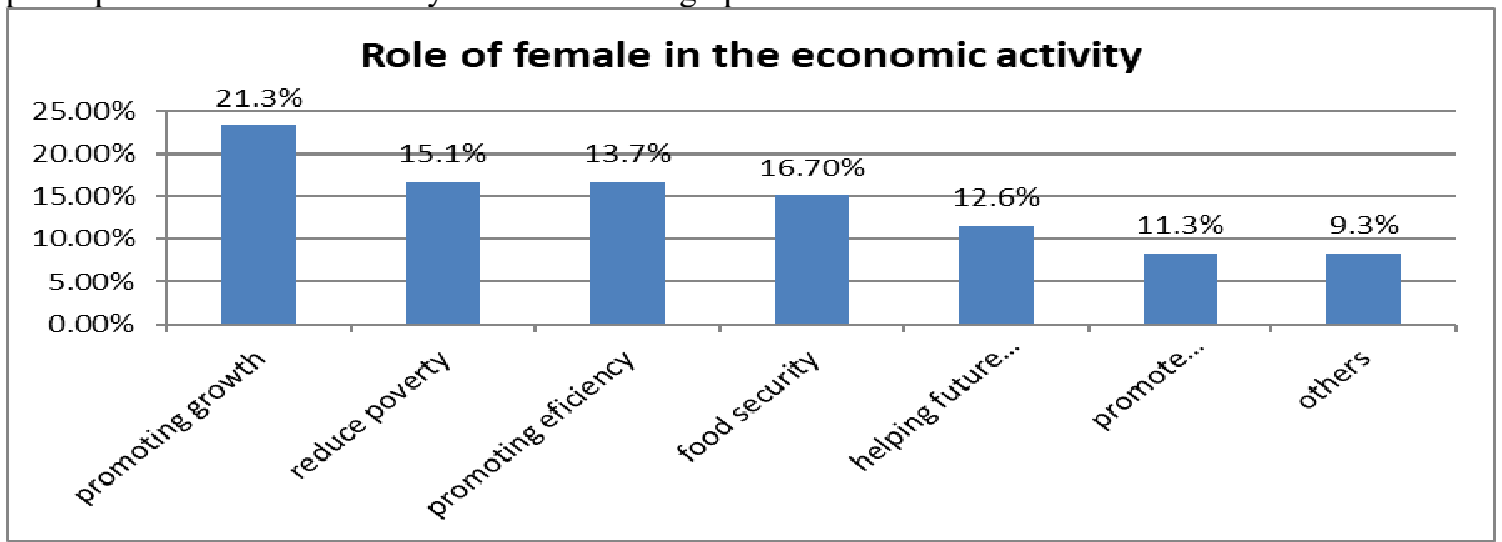

Figure: Role of female participation in the economic Activity on the economy.

Sources: own computation

The role of female participation in economic activity on economy suggested by the respondents. Like discussed earlier ,this also clearly shows that the participation of female is economic activity is highly promoting growth (21.3\%),Reduce poverty (16.7\%) ,promoting efficiency (13.7\%) ,food security (15.1\%), helping future generation $(12.6 \%)$,promote sustainable development $(11.3 \%)$ and other $(9.3 \%)$ is suggested by the respondent female participation impact on economic activity on the economy.

\section{CONCLUSION AND RECOMMENDATIONS CONCLUSION}

Female constitute proportionally a larger group of labor force in various economic activities. Therefore 
economic development is unthinkable without the active participation of female.

Female participation in economic activities is critically for the economy. It speeds growth by productivity, food security, reduce poverty, and promote efficiency, helping future generation and sustainable development.

female participation in economic activities is expected to improve personal well-being investment enable households to feed themselves and their family members, housing condition, nutrition and access to participation of female in economic activity like lack is creditability, legal regulatory, barrier, dual role in house and home. Suggestion given by the respondent to the financial institution and bank, promote income generating activities, promote to Forum association and educate them to generate the positive impact on the household.

Based on this, finally we can say that female participation in economic activities over significant roles in household wealth and countries economy, but it is lagged behind. When compare with the number is men engaged around. This is credit facility, legal and regulatory barriers and dual role in home and market place.

\section{RECOMMENDATIONS}

The principal strategies for increasing female participation in the economic activities including removing legal and regulatory barriers, raising female's productivity, easing the constraints on their time and improving the efficiency of the economic participation, providing information on the job opportunities, legal reform, educating and training, improving access to information and providing affordable child care in addition to mother care the key for female participation in economic activities.

It is essential to improve the level of income of a woman, and to facilitate their labor in the appropriate place and improve their education. It is necessary to facilitate favorable condition for the formation of association as well as strengthen the existing associations, so that female can solve their own problems.

As all, it is only when these conditions are facilitated that female can participate in the national development effort on equal terms with the men counterpart and benefit from their participation. The necessity of planning out what must be done, drawing lessons from past experiences, and believing that female's issues or concern not only female but also society at large and that female's problem cannot be solved by female alone but by coordinating effort of the society, the government and female is necessary.

Policy maker and development practitioners must consider gender difference implications of development for interventions of female at each strategy of policy project development for economic sector. In addition, government should: Improve access up female to credit, avoiding legal and regulatory barriers, help female to get recognition, as they are productive enough and have the capacity to participate to participate in the economic activity in both household and nation at large.

\section{Reference}

Boserup Easter (2010), female's role in economic development ." CEEPA DP35, University of Pretoria, South Africa. Kenya National Bureau of Statistics (1975-2012). Kenya Economic Survey. Government Printer, Nairobi.

Food policy report (1995), FEMALE's the key to food security Review of Economics and Statistics 24, pp.312320.

IFPRI (2001), Facts on female and development research conducted by the international food and policy research institute: The Case of Chinese Agricultural Growth before and After Reform, Amer J.Agri.Econ, Vol.78, No.2, pp.331-338.

International Labor Organization (1986), female's employment patters and discrimination World Bank Environment Department Paper 91, World Bank, USA.

John R. weeki (2002), Female and development: In: Women and International Development Annual Report, Vol. 1. Gallin, R. and Ferguson, A. (ed). Westview Press, USA.

M.P Todaro and S.L Smith (2009), Economic development, $10^{\text {th }}$ edition,_A Study of Farmers Within and Outside the Sasakawa-Global 2000 Project. Agricultural Economics, Vol. 19, No.3, pp.341-348.

Ethiopian Economic Associating (2000), A Mixed Random Approach. Applied Econometrics, Vol. 29, pp.12171226: Sharada weir Working Paper Series, University of Oxford

Office of prime minister (2001), National policy on Ethiopian female's: International Economic Review, Vol. 14, No. 1, pp.693-09.

MEDaC (Ministry of Economic Development and Cooperation)(2014). Survey and Current Economic Conditions in Ethiopia, Unpublished Paper, Addis Ababa.

Yirgedu (2001), FEMALE labor force participation Gender and development: Journal of the Society for International Development, No. 1-4, p.37.

World Bank (1994), Enhancing female's economic development . Report no. 53707-ke, World Bank, USA.

World Bank (1994), Toward gender equality." International Development International Development Working Paper 57, Michigan State University, USA 